\title{
AN ERROR ANALYSIS OF ENGLISH FOREIGN LANGUAGE LEARNING IN THE TERMINAL MOVIE
}

\author{
Suswanto Ismadi Megah S. \\ English Dept., Univerisityy of Riau Kepulauan, Batam, Indonesia \\ megah76@yahoo.co.id
}

\begin{abstract}
This study identified how the foreigner survived in communication when he 'trapped' almost a year at the John F. Kennedy International Airport. human being needs to interact with others as they fulfill their needs by using communication tool such as language in a society. Hence, this study idenfied how he learnt at the airport to communicate with other people. it is important thing of human life, people need communication to share idea, opinion, or feelings to others. In addition, good interaction when they can communicate their tough well. But the problem is conducting a good relationship with the others is not an easier matter. This study took data from transcription of the dialoque of the main character. The data analyzed descriptively. To have speaking ability, student must be train to use English in communication orally.Eventually, the result of the study shows that the main character could communicate English well.
\end{abstract}

Keywords: Analysis, Error, and Foreign Language Learning.

Abstrak

Studi ini mengidentifikasi bagaimana orang asing selamat dalam komunikasi ketika dia terjebak 'hampir setahun di Bandara Internasional John F. Kennedy. manusia perlu interact dengan orang lain karena mereka memenuhi Ulasan kebutuhan mereka dengan menggunakan alat komunikasi seperti bahasa dalam masyarakat. Oleh karena itu, penelitian ini diidenfikasi bagaimana ia di bandara untuk communicate dengan orang lain. itu adalah hal yang penting dalam kehidupan manusia, orang perlu komunikasi untuk berbagi ide, pendapat, atau perasaan kepada orang lain. Selain itu, interaksi yang baik ketika mereka dapat communicate Ulasan sulit mereka dengan baik. Tapi masalahnya adalah melakukan hubungan yang baik dengan orang lain bukanlah hal yang mudah. Penelitian ini mengambil data dari transkripsi Dialoque dari karakter utama. Data dianalisis secara deskriptif. Untuk memiliki kemampuan berbicara, siswa harus melatih untuk menggunakan bahasa Inggris dalam komunikasi orally.Eventually, hasil penelitian menunjukkan bahwa karakter utama bisa communicate bahasa Inggris dengan baik.

Kata kunci: Analisis, Kesalahan, dan Belajar Bahasa Asing 


\section{INTRODUCTION}

Communication is a thing that it is very difficult to be avoided in daily normal life of human being. Due to human being needs to interact with others as they fulfill their needs by using communication tool such as language in a society. Therefore, it is important thing of human life, people need communication to share idea, opinion, or feelings to others. In addition, good interaction when they can communicate their tough well. But the problem is conducting a good relationship with the others is not an easier matter. So, in society human being uses a language. Holmes (2005) explains that sociolinguistics studies a language in society. She adds that in society need what it is called as common language, namely language used among people who have different mother tongue. For example English nowadays considered as an international language. Therefore, many people from many different countries try to learn English. Some countries still consider English as foreign language.

According to Busman (1996:627) language is vehicle for the expression or exchanging of thoughts, concepts, knowledge and information as well as the fixing and transmission of experience and knowledge. There some ways in learning language such as communicative approach and grammar approach are so significance approach learning of foreign language. In English learning process the student must competence on four skills in English, they are: speaking, listening, writing, and reading. Especially speaking is used to express their ideas and to communicate to people in the world. It is very important to master speaking well. To have speaking ability, student must be train to use English in communication orally. The mastery of speaking skills in English is a priority for many second or foreign language learners. Learners consequently often evaluate their success in language learning as well as the effectiveness of their English course on the basis of how well they feel they have improved in their spoken language proficiency.

So, English is very important in international communication, when we go to foregn countries with different mother, English is a solution to communicate with foreign people. More particularly when we go to English countries such as Unite d Kingdom, USA, Australia, etc English is a must. Therefore, psychologically study foreign language needs a challenge such as going abroad. 
It is based the explanation above, in this study, it is aimed to focuses on foreigner who acne to USA with special purpose but he cannot speak English. This is very interesting to study how he survives in his communication in English. This case can be studied psychological aspects of learning language such as in the "The Terminal" movie. It tells a man adapts and sets up residence in the airport, which makes the man who placed him there unhappy, as it seems he is in line for a promotion but he presence might complicate that.. With a strong survival instinct, he has makes friends with some of the people who work in the airport is attracted to a flight attendant .

This study analyze a man who names Viktor Navorski who came from an Eastern European country arrives in New York. However after he left his country war broke out. Suddenly Navorski is a man without a country - or one that the U.S. cannot recognize, thus he is denied entrance to the U.S. However, he also can't be deported so he is told by the Security Manager that he has to remain in the airport until his status can be fixed. And also Navorski doesn't speak English very well, so he cannot talk to or understand anyone. But he somehow adapts and sets up residence in the airport, which makes the man who placed him there unhappy, as it seems he is in line for a promotion but Navroski presence might complicate that. So he tries to get Navorski to leave but Navorski remains where he is. Navorski makes friends with some of the people who work in the airport and is attracted to a flight attendant he runs into whenever she comes in.

Therefore, as quoted by Pateda, (1990:11) say that Psycholinguistic investigates the interaction of language and mind in processing and producing utterances and in language acquisition. Osgood and Sebeok as quoted by Pateda, (1990:11) argue that Psycholinguistics deals directly with the process of encoding and decoding as they relate states of message to states of communicators. Hence, this study aimed to analyze the errors done by the main character in the Terminal movie. Then the study analysis limited of the grammar errors 


\section{UNDERLYING THEORY OF FOREIGN LANGUAGE LEARNING}

In language learning is a process of comprehension requires that listeners take in utterances analyze it. According to Clark (1977: 298) nativist propose the lanaguage acquisition is the result of innate capacity to language is thus only found in human being.

A foreign language, therefore is one which is not in common use in the social setting in which the individual is placed. For example, Russia, French, Italian or Spanish, Indonesia will consider definitely English as foreign languages.

\section{Concept of Language}

Firstly, in the Since the first god created the world, they have had their own ways in communication. Every creature to develop its own way to show the expression in communication, specially human. When people are already in the society, they start to create their language plays an important role in communication. According to Brown (1994:4) 'Language is a system of communication by sound, operating through the organ of speech and hearing, among member of a given community and using vocal symbols possessing arbitrary conventional meaning". Therefore, in communication language is very important in understanding of language. Every language has its own system, especially English. It has specific pronunciation and grammar. So, many people who learns English has mistakes or errors in their pronunciation and grammar.

There are so many languages used in the world, but the most generally spoken language is English. People all over the world use English as the international language. Through a language, someone is able to communicate with other people. Language has many advantages in real life as : to talk with each other, to express the idea and also to transfer knowledge and culture.

According to Finicchiro (1964: 8) states " language is system of arbitrary vocal symbol with permits all people in given culture or other people who have learned the system of that culture to communicate or interact". So, language has important role in our life with the function language as a tool of communication. People need to develop their language skill in 
human activities. With the language we are able to get the language permits practically all human activities both social and private. We also use language basically everything we doing involving often person. It is primary function in communication, transference message between two or more individual and himself.

\section{Errors in Error Analysis}

According to Brown (2001:221) having examined procedures of error analysis used to identify errors in second language learner production data, our final step in the analysis of erroneous learner speech is that of determining the source of error. Why are certain errors made? What cognitive strategies and styles or even personality variables underlie certain errors? While the answers the these questions are somewhat speculative in that sources must be inferred from available data, in such questions lies the ultimate value of learner language analysis in general. By trying to identify sources we can take another step toward understanding how to learner's cognitive and affective processes relate to the linguistic system and formulate an integrated understanding of the process of second language acquisition.

There is a danger in too much attention to learner's errors. While errors indeed reveal a system at work, the classroom language teacher can become so preoccupied with noticing errors that the correct utterances in the second language go unnoticed. In our observation and analysis of errors-for all that they do reveal about the learner-we must beware of placing too much attention on errors and not lose sight of the value of positive reinforcement of clear, free communication. While the diminishing of errors is an important criterion for increasing language proficiency, the ultimate goal of second language learning is the attainment of communicative fluency. Furthermore, Brown (2001:274) adds that people may learn second or foreign language as the same how to acquire the first language so the errors o mistakes may occur like the first language acquisition.

\section{Classification of Errors}

According to Dullay (1980:146), there are four types there are four types of description taxonomies which concern with the mistakes of errors are divided into four kinds, namely: 
a. Linguistic based category.

Linguistic based category classifies errors according ton either or both the language component and the particular linguistic the errors affect.

b. Communicative affect

The communicative affect classification deals with errors from the perspective of their affect on the listener or reader. It focuses on distinguishing between errors to cause mis communication.

c. Comparative analysis

The classification of the errors is based on comparison between the structure of errors and certain other types of construction.

d. Surface strategy

It highlights the way surface structure are alerted. The learner may omit necessary item or add unnecessary ones; they may misinform item or misorder them.surface strategy is divided into fourth; they are omission errors, addition errors, disordering errors, and misinformation errors. From those theories the writer would like to focus on the surface strategy. The following part is synopsis of the "Terminal Movie". It issued because the data will be obtained from the movie as explained in following chapter.

\section{Mistakes or Error of the Second and Foreign Language Learning}

Brown (2001:217) by the late 1960s, SLA began tobe examined in much the same way the first language acquisition had been studied for some time: learners were looked on not as procedures of malformed, imperfect language replete with mistakes but as intelligent and creative beings proceeding through logical, systematic stages of acquisition, creatively acting upon their linguistic environment as they encountered its forms and functions in meaningful contexts. By a gradual process of trial and error and hypothesis testing, learners slowly and tediously succed in establishing closer and closer approximations to the system used by native speakers of the language. A number of terms have been coined to describe the perspective that stresses the legitimacy of learners second language systems. The best known of these is 
interlanguage, a term that Selinker (1972) adapted from Weinreich's (1953) term "interlingual." Interlanguage refers to the separateness of a second language learner's system, a system that has a structurally intermediate status between the native and target languages.

According to Namser ( 1971) in Brown (2001:217) referred to the same general phenomenon in second language learning but stressed the successive approximation to the target language in his term approximate system. Corder (1971:152) used the term idiosyncratic dialect to connote the idea that the learner's language is unique to a particular individual, that the rules of the learner's language are peculiar to the language of that individual alone. While each of these designations emphasizes a particular notion, they share the concept that second language learners are forming their own self-contained linguistic systems. This is neither the system of the native language nor the system of the target language, but a system based upon the best attempt of learners to bring order and structure to the linguistic stimuli surrounding them. The most obvious approach to analyzing interlanguage is to study the speech and writing of learners, or what has come to be called learner language ( Lightbown \& Spada 1993; C. James 1990). Production data is publicly observable and is presumably reflective of a learner's underlying competence -production competence, that is. Comprehension of a second language is more difficult to study since it is not directly observable and must be inferres from overt verbal and nonverbal responses, by artificial instruments, or by the intuition of the teacher or researcher.

It follows that the study of the speech and writing of learners is largely the study of the errors of learners. "Correct" production yields little information about the actual linguistic system of learners, only information about the target language system that learners have already acquired. Therefore, our focus in the rest of this chapter will be on the significance of errors in learner's developing systems, otherwise known as error analysis.

Human learning is fundamentally a process that involves the making of mistakes. Mistakes, misjudgments, miscalculations, and erroneous assumptions form an important aspect of learning virtually any skill or acquiring information. You learn to swim by first jumping into the water and flailing arms and legs until you discover that there is a combination of movements - a structured pattern - that succeeds in keeping you afloat and propelling you through the water. 
The first mistakes of learning to swim are giant ones, gradually diminishing as you learn from making those mistakes. Learning to swim, to play tennis, to type, or to read all involve a process in which success comes by profiting from mistakes, by using mistakes to obtain feedback from the environment, and with that feedback to make new attempts that successively approximate desired goals.

Language learning, in this sense, is like any other human learning. We have already seen in the second chapter that children learning their first language make countless"mistakes" from the point of view of adult grammatical language. Many of these mistakes are logical in the limited linguistic system within which children operate, but, by carefully processing feedback from others, children slowly but surely learn to produce what is acceptable speech in their native language. Second language learning is a process that is clearly not unlike first language learning in its trial-and-error nature. Inevitably learners will make mistakes in the process of acquisition, and that process will be impeded if they do not commit errors and then benefit from various forms of feedback on those errors.

According to Brown (2001:216) Researchers and teachers of second languages came to realize that the mistakes a person made in this process of constructing a new system of language needed to be analyzed carefully, for they possibly held in them some of keys to the procces of second language acquisition. According to Corder (1967: 167) notes “A learner's error are significant in [that] they provide to the researcher evidence of how language is learned or acquired, what strategies or procedures the learned ar acquired, what strategies or procedures the learner is employing in the discovery of the language."

\section{Mistakes and Errors}

Errors and mistakes are being idea about something. Error are students false utterance or sentences in speaking or writing because they have lack of the knowledge of english structure.

To make it clear, the writer will describe about the between errors and mistakes. Because both of them are simile in meaning but in language study are different.

According to Brown ( 1994 :205 ) states “ a mistakes refer to performance error that is either a random guess or "slip " in that is a failure to utilize a known system correctly". It means 
learner have known the rule in making sentences before, it is out of condition of the learner such as miswriting and fatigue.

According to Brown ( 1994 : 205 ) states “ error is noticeable deviation from the adult grammar of native speaker, reflecting interlingua competence of the learner". In teaching and learning, the students must be able to communicate into spoken or written. Of course, the students are able to speak and write well. It also needs students ability, they will be able to speak and write english well. Based on the theory above, it is clear that in using language the students must have the ability of structure.

So, the different between error and mistakes is that errors is ungrammatical utterance which refer to the language competence and mistake is unperfectness of utterance which refer to the language performance.

In order to analyze learner language in an appropriate perspective either second or foreign language learning, it is crucial to make a differences between mistakes and errors. According to Brown (2001:218) a mistake refers to a performance error that is either a random guess or a "slip," in that it is a failure to utilize a known system correctly.

So, many people can make mistakes, in both native and second language situations. Native speakers are normally capable of recognizing and correcting such "lapses" or mistakes, which are not the result of a deficiency in competence but the result of some sort of temporary breakdown or imperfection in the process of producing speech. These hesitations, slips of the tongue, random ungrammaticalities, and other performances lapses in native-speakers production also occur in second language speech. Mistakes, when attention is called to them, can be selfcorrected.

Mistakes must be carefully distinguished from errors of a second or foreign language learner, idiosyncrasies in the language of the learner that are direct manifestations of a system within which a learner is operating at the time. According to Brown (2001:218) An error, a noticeable deviation from the adult grammar of a native speaker, reflects the competence of the learner. 


\section{Suswanto: Errors Analysis of English....................}

Brown (2001:218)adds that learners of English who ask,'Does John can sing?" are in all likelihood reflecting a competence level in which all verbs require a pre-posed do auxiliary for question formation. As such, it isa error, most likely not a mistake, and an error that reveals a portion of the learner's competence in the target language. In addition, James (1998:83), while mistakes can be self-corrected if the devitation is pointed out to the speaker. But the learner's capacity for self-correction is objectively observable only if the learner actually self-correcs; therefore, if no such self-correction occurs, we are still left with no means to identify error vs. mistake. So, can we turn to frequency of a deviant form as a criterion?.

James (1998:83)states that sometimes. If, on one or two occasions, an English learner says "John cans sing", but on other occasions says "John can sing,"it is difficult to determine whether "cans "is a mistake or an error. If, however, further examination of the learner's speech consistently reveals such utterances as "John will go," "John mays come," and so forth, with very few instances of correct third person singular usage of modal auxiliaries, you might safely conclude that "cans", "mays" and other such form are errors indicating that the learner has not distinguished modals from other verbs.

In addition, Brown (2001:219)The fact that learners do make errors, and that these errors can be observed, analyzed, and classified to reveal something of the system operating withtin the leaner, led to a surge of study of learner's errors, called error analysis. Error analysis became distinguished from cantrastive analysis by its examination of errors attributable to all possible sources, not just those resulting from negative transfer of the native language. Error analysis easily superseded contrastive analysis, as we discovered that only some of the errors a learner makes are attributable to all the errors contrastive analysis predicted they should, and that learners from disparate language backgrounds tend to make similar errors in learning one target language.

\section{Errors in Error Analysis}

Brown (2001:220) there is a danger in too much attention to learner's errors. While errors indeed reveal a system at work, the classroom language teacher can become so preoccupied with noticing errors that the correct utterances in the second language go unnoticed. In our 
observation and analysis of errors-for all that they do reveal about the learner-we must beware of placing too much attention on errors and not lose sight of the value of positive reinforcement of clear, free communication. While the diminishing of errors is an important criterion for increasing language proficiency, the ultimate goal of second language learning is the attainment of communicative fluency.

Moreover Brown (2001:220) another shortcoming in error analysis is an overemphasis on production data. Language is speaking and listening, writing and reading. The comprehension of language is as important as production. It iso happens that production lends itself to analysis and thus becomes the prey of researchers', but comprehension data is equally important in developing an understanding of the process of Second Language Acquisition (SLA).

In addition, James (1998:84) over the years, many studies have shown that error analysis fails to account for the sttategy of avoindance. A learner who for one reason or another avoids a particular sound, word, structure, or discourse category may be assumed incorrectly to have no difficulty therewith. Finally, error analysis can keep us too closely focused on specific languages rather than viewing universal aspects of language. Therefore, in the analysis of learners' errors, to engage in "performance analysis" or " interlanguage analysis" . according to Celce-Murcia \& Hawkins (1985 : 64), a less restrictive concept that places a healthy investigation of error within the larger perspective of the learner total language performance. While significant portion of this chapter deals with error analysis, let us nevertheless remember that production error are only a subset of the overall perfomanse of the learning.

\section{Identifying and Describing Mistakes and Errors}

Brown (2001:221) one of the common difficulties in understanding the linguistic systems of booth first and second language learners iss the fact that such system cannot be directly observed. They must be inferred by means of analyzing production and comprehension data. Systems are in a constants state of flux as new information flows in and, through the process of subsumption, causes existing structers to be revised. Repeated obvervations of a learner will often reveal apparently unpredictable or even contradictory data. 
The first step in the process of analysis is the identification and description of errors. Corder (1971) in Brown (2001:221) provides a model for indentifiying erroneous or idiosyncratic utterance in a second language. According to Corder's model, any sentence uttered by the learner and subsequently transcribed can be analyzed for idiosyncrasies. Overtly erroneous utterances are unquestionably ungrammatical at the sentence level. Covert errors, in other words, are not really covert at all if you attend to surrounding discourse (before or after the utterance).

\section{Sources of Mistakes or Errors}

According to Brown (2001:221) having examined procedures of error analysis used to identify errors in second language learner production data, our final step in the analysis of erroneous learner speech is that of determining the source of error. Why are certain errors made? What cognitive strategies and styles or even personality variables underlie certain errors? While the answers the these questions are somewhat speculative in that sources must be inferred from available data, in such questions lies the ultimate value of learner language analysis in general. By trying to identify sources we can take another step toward understanding how to learner's cognitive and affective processes relate to the linguistic system and formulate an integrated understanding of the process of second language acquisition.

Therefore, it is based on the above that Foreign or second Language Learning: according to Brown (2001:274) people may learn second or foreign language as the same how to acquire the first language so the errors o mistakes may occur like the first language acquisition.

\section{Mistakes of Dispelling}

The first step in investigating age and acquisition might to be dispel some myths about the relationship between first and second language acquisition.H.H.Stern (1970:57-58) summarized some common arguments that cropped up from time to time to recommend a second language teaching method or procedure on the basis of first language acquisition:

1. In language teaching, we must practice and practice, again and aagain. Just watch a small child learning his mother tongue. He repeats things over and over again. During the language learning stage he practices all time. This is what we must also do when we learn a foreign language. 
2. Language learning is mainly a matter of imitation. You must be a mimic. Just like a small child. He imitates everything.

3. First, we practice the separate sounds, then words, then sentences. That is the natural order and is therefore right for learning a foreign language.

4. Watch a small child's speech development. First he listens, then he speaks. Understanding always precedes speaking. Therefore, this must be the right order of presenting the skills in a foreign language.

5. A small child listens and speak and no one would dream of making him read or write. Reading and writing are advanced stages of language development. The natural order for first and second language learning is listening, speaking, reading, writing.

6. You did not have to translate when you were small. If you were able to learn your own language without translation. Yo shoud be able to learn a foreign language in the same way.

7. A small child simply uses language. he does not learn formal grammar. You don't tell him about verbs and nouns. Yet he learns the language perfectly. It is equally unnecessary to use grammatical conceptualization in teaching a foreign language.

These statements represent the views of those who felt that"the first language learner was looked upon as the foreign language teachers dream: a pupil who mysteriously laps up his vocabulary, whose pronounciation, in spite of occasional lapses, is impeccable, while morphology and syntax, instead of being a constant headache, come to him like a dream' ( Stern 1970:58). The statements also tend to represent the views of those who were dominated by a behavioristic theory of language in which the first language acquisition process was viewed as consisting of rote practice, habit formation, shaping, overlearning, reinforcement, conditioning, association, stimulus and response, and who therefore assumed that the second language learning process involves the same construct.

There are flaws in each view, sometimes the flaws is in the assumption behind the statements about first language learning, and sometimes it is in the analogy or implication that is drawn; sometimes it is in both. The flaws represent some of the misunderstandings that need to be demythologized for the second language teacher. Through a careful examination of those 
shortcomings in this chapter, you should be able, on the one hand, to avoid certain pitfalls, and on the other hand, to draw enlightened, plausible analogies wherever possible, thereby enriching your understanding of the second language learning process itself.

As cognitive and constructivist research on first language acquisition gathered momentum, second language researchers and foreign language teacher began to recognize the mistakes in drawing direct global analogies between first and second language acquisition. Some of the first warning signals were raised early in the process by the cognitive psychologist Ausubel (1964). In foreboding terms, Ausubel outlined a number of glaring problems with the then-popular Audiolingual Method, some of whose procedures were ostensibly derived from notions of'natural" (first) language learning. He issued the following warnings and statements.

- The rote learning practice of audiolingual drills lacked the meaningfulness necessary for successful first and second language acquisition.

- Adults learning a foreign language could, with their full cognitive capacities, benefit from deductive presentations of grammar.

- The native language of the learner is not just an interfering factor-it can facilitate learning a second language.

- The written form of the language could be beneficial.

- Students could be overwhelmed by language spoken at its"natural speed," and they, like children,could benefit from more deliberative speech from the teacher.

These conclusions were derived from Ausabel's cognitive perspective, which ran counter to prevailing behavioristic paradigms on which the Audiolingual Method was based. But Ausabel's critism may have been ahead of its time, for in 1964 few teachers were ready to entertain doubts about the widely accepted method. (See the vignette at the end of this chapter for a further discussion of the Audiolingual method.)

By the 1970s and 1980s, criticsm of earlier direct analogies between first and second language acquisition had reached full steam. Stern (1970), Cook (1973, 1995), and Schachter (1988), among others, addressed the inconsistencies of such analogies, but at the same time recognized the legitimate similarities that, if viewed cautiously, allowed one to draw some constructive conclusions about second language learning. 


\section{b.7 Grammar Errors}

According to Dykes (2007:14) states " The word grammar often invokes a negative reaction in both teacher and students". When thinking about grammar many people probably imagine a book full of explanation and rules that tell them which verb have what endings, how to use adverbs, how to use modal, how to use preposition, and how to use conjunction. The word grammar is very ambiguous since it has several meaning". There is no fixed definition of grammar because many expert often define the term of grammar differently. Grammar may mean an analytical and terminological study of sentences. thus, when we learn the grammar we will learn the part of speech, their name and their description, we will learn such term of phrase, clause, interrogative sentence, retained object, ect.

\section{METHODOLOGY}

This study apply descriptive qualitative research due to this data found consist of words. According to Creswell (2003:74) a research problem can originate from many potential sources. The writer collects data through observation toward the movie by watching many times, then he comes up with a theory to analyze the data. So, this study can be classified in the field of qualitative research. Moleong (2009: 4) states that the type of this study is "Descriptive Qualitative Research". Qualitative research is the procedure of research which produces descriptive data that is written or oral word from the people and the behaviors which are observed. Hence, this study has some process of doing the study this is circular, having completed it by collecting the data based on the text of the dialogue among the characters but the focus on this study is the main character only. In addition, the errors are still wide range, therefore, the data analysis limited of the grammar errors.

\section{RESULT}




\section{Suswanto: Errors Analysis of English..................}

In this data analysis to focus on the grammar errors. So, the grammar is the systematized knowledge or theory of sentence structure. Grammar provides a whole cohesive system concerning the formation and transmission of language. Grammar may also be defined as the basic signals a language transmit meaning. Therefore, the data display below will be explained more detail..

\section{Data 1}

Mulroy : Well, why don't go home?

Viktor : I just arrived

The data 1 above shows that Mulroy says and Navorsky wrong of grammar "Well, why don't go home?". This shows that victor has mistake he omits (pronoun of “you) . This should be Well, why don't you go home? Therefore, he did errors of using second person by omitting "you".

\section{Data 2}

Viktor $\quad$ I.......I help you?

Cashier $\quad$ : Im so sorry sir, the position has already been filled

The data 2 above shows that Viktor say to Cashier wrong of grammar by using of "I help you?". This shows that the foreigner when he learns English as foreign language by using grammar. He should say “Can I help you?”. The above is an error of using English grammar.

\section{Data 3}




$\begin{array}{ll}\text { Viktor } & : \text { It's beautiful horse } \\ \text { Nadia } & : \text { Who said that? }\end{array}$

The data 3 shows that Viktor say to Nadia wrong of grammar by using of "beautiful horse?". This shows that the foreigner when he learns English as foreign language by using wrong grammar . He should say "beautiful horse" but it is not English expression, he just sees the picture so, he does wrongly to use good grammar. It makes misunderstand each others.

\section{Data 4}

Viktor : So, I answer one question. Go to New York

City tonight.

Dixon : Tonight

The data 4 above shows that Viktor talks with Dixon say of grammar by using of "go to New York". This shows that the foreigner when he learns English as foreign language by using wrong grammar by omitting "I will” . He should say "I will go to New York". So it makes Dixon confused to Victor what he means. So the dialogue is clear that the error done by the main character.

\section{Data 5}

Shopkeeper : : Yeah, so could you please go sit some place else?

Viktor : I go to bathroom now 
The data 5 above shows Viktor talks with Shopkeeper say of grammar by using of "go to bathroom". This shows that the foreigner when he learns English as foreign language with low understanding. He should say " okay, thank but he answers " go to bathroom' So the dialogue is clear that the error done by the main character to make shopkeeper confused.

\section{Data 6}

$\begin{array}{ll}\text { Dixon } & \text { : Are you sure you want to do that? } \\ \text { Viktor } & \text { : I go New York City now. }\end{array}$

This is based the data 6 above that Viktor talks with Dixon says of grammar by using of "are sure you want to do. This shows that the foreigner when he learns English as foreign language with low understanding. He should say "yes or not only" because eth question is Yes/no question. The above data shows error of the main character.

\section{Data 7}

Viktor : Now I go New York City. Thank you.

Dixon : No, Mr. Navorski. I cannot allow you

The data 7 above shows that Viktor talks with Dixon says of grammar by using of "now I go to New York City". This shows that the foreigner when he learns English as foreign language with low understanding. He should say "I go to New York City?". He did an error by saying as the above. 


\section{CONCLUSION}

This study can be concluded that in learning a foreign language has some features or steps the errors come. The analysis was focused on the main character that he tries communicating although the grammar still many errors. The grammar provides a whole cohesive system concerning the formation and transmission of language as in this study used by Victor as the main character. He still has lack of the English grammar mastery so errors occurred in communication among he and the hearers of the Terminal movie.

\section{REFERENCES}

Brown, H. Douglas. 2000. Principles of Language Learning and Teaching. New York: A Pearson Education Company

Brown, H. Douglas. 2001. Teaching by Principles: and Interactive Approach to Language Pedagogy. New York: A Pearson Education Company

Moseley, David., et al. 2005. Frameworks for Thinking. New York: Cambridge University Press.

Moeleong Lexy.J.2004. Metodologi Penelitian Kualitatif. Bandung : Remaja Rosdakarya

Rivers, Wilga. M. 1981. Teaching Foreign-Language Skills. Chicago: The University of Chicago Press.

Thornbury, Scott. 2005. How to Teach Speaking. New York: A Pearson Education Company. 